\title{
PENGARUH PROBLEM BASED LEARNING (PBL) TERHADAP KEMAMPUAN HEURISTIK PEMECAHAN MASALAH DAN SIKAP MATEMATIS SISWA SEKOLAH DASAR
}

\author{
Diding Ruchaedi ${ }^{1}$ ) dan Ilham Baehaki ${ }^{2}$ ) \\ didingruchaedi14@gmail.com
}

\begin{abstract}
ABSTRAK
Penelitian ini dilatarbelakangi oleh rendahnya kemampuan Heuristik pemecahan masalah dan sikap matematis siswa terhadap pelajaran matematika. Penelitian ini bertujuan untuk menelaah perbedaan peningkatan kemampuan pemecahan masalah dan sikap matematis siswa yang menggunakan Problem Based Learning ( $P B L)$ dengan siswa yang menggunakan pembelajaran konvensional. Metode dalam penelitian ini menggunakan desain kuasi eksperimen dengan subjek penelitian seluruh siswa kelas V SD Negeri Leuwikujang I sebagai kelas eksperimen dan seluruh siswa kelas V SD Negeri Rajawangi I sebagai kelas kontrol. Instrumen yang digunakan adalah tes kemampuan pemecahan masalah dan skala sikap matematis siswa. Data hasil penelitian berupa skor pretes dan postes siswa dianalisis dengan menggunakan uji $t$ dan uji korelasi Product Moment Pearson. Berdasarkan hasil analisis data diperoleh dapat ditarik kesimpulan bahwa, siswa yang mendapatkan pembelajaran Problem Based Learning $(P B L)$ mengalami peningkatan pada kemampuan strategi heuristic pemecahan masalah dan sikap matematis yang lebih baik dibandingkan dengan siswa yang mendapatkan pembelajaran matematika secara konvensional.
\end{abstract}

Kata Kunci: Problem Based Learning (PBL), heuristik pemecahan masalah, sikap matematis.

\begin{abstract}
This research is motivated by the low ability of heuristic problem solving and mathematical student attitudes toward math. This study aimed to examine the differences in upgrading of mathematical problem solving and attitude of students who use the Problem Based Learning (PBL) with students who use conventional learning. The method in this study used a quasiexperimental design with research subjects throughout Elementary School fifth grade students Leuwikujang I as an experimental class and all students of class V Elementary School Rajawangi I as the control class. The instrument used was a test problem-solving ability and attitude scale mathematical students. Research data in the form of student pretest and posttest scores were analyzed using $\mathrm{t}$ test and Pearson Product Moment Correlation. Based on the analysis of data obtained it can be deduced that, students who receive learning Problem Based Learning (PBL) has increased the ability of heuristic problem-solving strategies and mathematical attitude better than students who received conventional mathematics.
\end{abstract}

Keywords: Problem Based Learning (PBL), heuristic problem solving, mathematical attitude.

\footnotetext{
${ }^{1}$ Penulis adalah Guru SDN Rajawangi II Kab.Majalengka

${ }^{2}$ Penulis adalah Guru SDN Cempaka Kab. Cianjur
} 


\section{A. Pendahuluan}

Tujuan Mata Pelajaran Matematika di SD termuat dalam Standar Isi (SI) pada Permendiknas Nomor 22 Tahun 2006. Dalam SI tersebut dinyatakan lima tujuan pembelajaran matematika, yang salah satu dari lima tujuan tersebut adalah agar siswa mampu memecahkan masalah matematika yang meliputi kemampuan memahami masalah, merancang model matematika, menyelesaikan model dan menafsirkan solusi yang diperoleh. Oleh karena itu setiap guru SD harus melatih keterampilannya dalam membantu siswa belajar memecahkan masalah matematika.

Kemampuan pemecahan masalah menjadi tujuan utama dari belajar matematika di antara tujuan yang lain. Menurut Holmes (dalam Wardhani, dkk, 2010, hlm. 7)pada intinya menyatakan bahwa "latar belakang atau alasan seseorang perlu belajar memecahkan masalah matematika adalah adanya fakta dalam abad duapuluh satu ini bahwa orang yang mampu memecahkan masalah hidup dengan produktif'. Ini berarti bahwa orang yang terampil memecahkan masalah akan mampu berpacu dengan kebutuhan hidupnya, menjadi pekerja yang lebih produktif, dan memahami isu-isu kompleks yang berkaitan dengan masyarakat global.

Kebanyakan siswa mengalami kesulitan dalam pemecahan masalah karena siswa tidak dapatmemaknai konsep yang terdapat dalam soal cerita, tidak dapat merumuskan soal cerita ke dalam model matematika, dan tidak dapat memilih dan menggunakan strategi penyelesaian yang tepat. Ini diakibatkan oleh pembelajaran matematika yang lebih menekankan pada keterampilan berhitung dari pada penguasaan konsep-konsep. Lidinillah (2008) mengatakan, bahwa "guru dalam pembelajaran masih fokus kepada pencapaian kemampuan siswa dalam berhitung dan mengunakan rumus matematika, sementara kemampuan pemecahan masalah siswa masih dianggap sebagai kemampuan ekstra atau tambahan". Banyak guru merasa cukup dengan pembelajaran perhitungan dan beranggapan bahwa pembelajaran pemecahan masalah menyita waktu yang sangat banyak, sehingga sering mengganggu program pembelajaran. Pada akhirnya pembelajaran pemecahan masalah menjadi terabaikan.

Dampaknya adalah kemampuan pemecahan masalah siswa dalam pemecahan masalah di sekolah dasar masih sangat rendah. Beberapa penelitian melaporkan bahwa kesulitan siswa SD pada umumnya dalam belajar matematika adalah dalam memahami soal dan menyelesaikan soal cerita. (Komariah, 2007). Siswa tidak mampu menerapkan konsep-konsep matematika ke dalam bentuk pemecahan masalah kehidupan sehari-hari.

Pemecahan masalah dilakukan melalui tahapan-tahapan berpikir yang disebut heuristik. Heuristik adalah suatu penuntun yang diperlukan dalam menyelesaikan suatu masalah yang dapat mengarahkan pemecah masalah untuk menemukan penyelesaian soal yang diberikan. Heuristik merupakan langkah berpikir dan upaya untuk menemukan dan memecahkan suatu masalah atau persoalan matematika. Lankah-langkah heuristik menurut Polya dalam Suherman (2001, hlm. 84) adalah 1) pemahaman terhadap masalah, 2) perencanaan penyelesaian masalah, 3) melaksanakan perencanaan penyelesaian masalah, dan 4) melihat kembali penyelesaian. Dalam pemecahan masalah matematika, siswa dihadapkan pada situasi yang mengharuskan mereka memahami masalah (mengidentifikasi unsur yang diketahui dan yang ditanyakan), membuat modelmatematika, memilih strategi penyelesaian model matematika, melaksanakan penyelesaikan model matematika dan menyimpulkan. Pada situasi ini, siswa diberikan kesempatan yang sebesar-besarnya untuk mengembangkan ide-ide matematikanya sehingga siswa dapat menggunakan 
heuristik agar dapat memecahkan masalah tersebut dengan baik

Pengembangan kemampuan siswa dalam pemecahan masalah dapat dilakukan dengan cara memberikan pengalaman pemecahan masalah yang dapat diselesaikan dengan heuristik yang berbeda-beda. Setiap masalah memerlukan cara penyelesaian yang berbeda-beda. Berbagai macam soal dalam matematika juga mempunyai kekhasan dan memerlukan strategi yang khaspula untuk menyelesaikannya. Heuristik ini secara utuh akan dapat dipahami dan dikuasai apabila sisea terbiasa melatih diri dengan berbagai macam tipe dan tingkat kesulitan soal-soal matematika. Heuristik tidak dapat dipisahkan dari kajian tentang pemecahan masalah matematika dan pembelajarannya. Jika siswa menguasai heuristik dalam pemecahan masalah, maka dapat dipastikan siswa tersebut memiliki kemampuan memecahkan masalah dengan baik.

Keberhasilan pembelajaran matematika juga dipengaruhi oleh berbagai faktor, salah satunya adalah faktor sikap siswa terhadap matematika. Sikap terhadap matematika meliputi tiga komponen, yakni komponen kognisi, afektif kognisi, dan konasi. Komponen kognisi tersusun atas dasar pengetahuan dan informasi yang dimilki seseorang tentang objek sikapnya, komponen afeksi bersifat evaluatif yang berhubungan dengan rasa senang dan tidak senang, dan komponen konasi adalah kesiapan seseorang untuk bertingkah laku yang berhubungan dengan objek sikapnya atau komponen yang berhubungan dengan kecenderungan bertindak terhadap objek. Sikap matematis siswatidak dapat diabaikan dalam pembelajaran matematika karena memberikan pengaruh terhadap pembelajaran.

Mengetahui sikap siswa pada pembelajaran matematika sangatlah penting dalam mendukung keberhasilan guru mengajarkan matematika. Jika kemampuan pemecahan masalah matematika rendah, akan mengakibatkan siswa memiliki sikap yang negatif terhadap pembelajaran matematika, atau sebaliknya sikap negatif siswa terhadap matematika dapat mengakibatkan kemampuan pemecahan masalah matematika siswa rendah. Sehingga guru dituntut dapat menghilangkan sikap negatif dandan dapat menanamkan sikap positif siswa terhadap matematika.

Rendahnya kemampuan pemecahan masalah dan sikap matematis akan berdampak pada intelektual dan non intelektual siswa. Dari segi intelektual, siswa tidak mampu menerapkan konsepkonsep matematika dalam pemecahan masalah. Dari segi non intelektual, siswa tidak dapat mengembangkan sikap secara optimal dalam mengembangkan rasa ingin tahu, ketekunan, ketelitian, dan rasa percaya diri dalam pemecahan masalah. Padahal semua itu dibutuhkan oleh siswa untuk kebutuhan hidupnya.

Oleh karena itu dibutuhkan model pembelajaran yang dapat meningkatkan kemampuan heuristik pemecahan masalah dan dapat mengembangkan sikap matematis siswa dalam penyelesaian soal cerita. Salah satu model pembelajaran yang diduga dapat meningkatkan kemampuan pemecahan masalah dan sikap matematis siswa adalah Problem Based Learning $(P B L)$. PBL menyajikan masalah autentik untuk dapat dirumuskan dan dipecahkan bersama dalam kelompok. Menurut Arends (2008, hlm. 41), PBL merupakan pembelajaran yang memiliki esensi berupa menyuguhkan berbagai situasi bermasalah yang autentik dan bermakna kepada siswa.

PBL dapat memfokuskan siswa pada proses pembelajaran dan mengaktifkan siswa untuk menemukan kembali konsep-konsep, melakukan refleksi, abstraksi, formalisasi, pemecahan masalah, komunikasi dan aplikasi. PBL juga dapat mendukung proses pembelajaran matematika yang menyenangkan dan terpusat pada siswa. Siswa diberi kesempatan untuk 
menemukan persoalan yang ada disekitarnya yang bisa dijadikan masalah dalam proses pembelajaran. Siswa diberi kesempatan untuk memikirkan penyelesaian dari masalah itu melalui diskusi dengan teman sekelasnya. Dengan demikian akan melatih siswa untuk berpikir kritis, kreatif, dan dapat memecahkan persoalan matematika yang dapat menumbuhkan kembangkan sikap positif siswa terhadap matematika.

Adapun tujuan dari penelitian ini adalah: 1) Menelaah pengaruh Problem Based Learning (PBL) terhadap kemampuan heuristik pemecahan masalah matematik siswa yang mendapat pembelajaran Problem Based Learning $(P B L)$ dengan siswa yang mendapat pembelajaran biasa. 2) Menelaah pengaruh Problem Based Learning (PBL) terhadap sikap matematis siswa yang mendapat pembelajaran Problem Based Learning $(P B L)$ dengan siswa yang mendapat pembelajaran biasa.

\section{B. Metode Penelitian}

Penelitian ini merupakan penelitian kuasi eksperimen atau eksperimen semu yang terdiri dari dua kelompok penelitian yaitu kelompok eksperimen (kelas perlakuan) merupakan kelompok siswa yang pembelajarannya menggunakan model pembelajaran Problem Based Learning $(P B L)$ dan kelompok kontrol (kelas pembanding) adalah kelompok siswa yang pembelajarannya tidak menggunakan model pembelajaran Problem Based Learning (PBL).

Pertimbangan penggunaan desain penelitian ini adalah bahwa kelas yang ada sudah terbentuk sebelumnya, sehingga tidak dilakukan lagi pengelompokkan secara acak. Apabila dilakukan pembentukan kelas baru dimungkinkan akan menyebabkan kekacauan jadwalpelajaran dan mengganggu efektivitas pembelajaran di sekolah.

Subjek penelitian ini adalah seluruh siswa kelas V SD Negeri Leuwikujang I sebagai kelas eksperimen yaiu kelas yang memperoleh model pembelajaran Problem Based Learning (PBL) dan seluruh siswa kelas V SD Negeri Rajawangi I sebagai kelas kontrol yang tidak mendapat perlakuan pembelajaran Problem Based Learning (PBL). .

Desain yang digunakan dalam penelitian ini adalah Nonequivalent Groups Pretes-Postest Design (Mc. Millan dan Schumacher, 2001, hlm. 342) yaitu:

$\begin{array}{ccc}\text { Pretes } & \text { Treatment } & \text { Postest } \\ \text { O } & \text { X } & \text { O } \\ \text { O } & \text { X } & \text { O }\end{array}$

Keterangan:

$\mathrm{O}$ : Pretes dan postest kemampuan heuristik pemecahan masalah dan sikap matematis

$\mathrm{X}$ : Perlakuan pembelajaran maternatika menggunakan Problem „,Based Learning $(P B L)$.

Instrumen penelitian ini terdiri dari tes berupa seperangkat soal tes soal cerita untuk mengukur kemampuan heuristik pemecahan masalah matematis dan angket untuk mengukur sikap matematis siswa. Tes kemampuan heuristik pemecahan masalah matematis disusun dalam bentuk uraian soal cerita. Hal ini mengingat pemecahan masalah merupakan kemampuan individu untuk menggabungkan pengetahuan, keterampilan, dan pemahaman yang sudah diperoleh sebelumnya untuk menyelesaikan masalah yang dihadapi.Pengukuran sikap matematis siswa dalam penelitian ini dengan menggunakan skala sikap model skala Likert. Kuesioner terdiri dari 20 pertanyaan yang berhubungan dengan sikap siswa pada pelajaran Matematika, yang terdiri dari 15 pernyataan positif dan 5 pernyataan negatif. Pada kuesioner ini juga dilakukan pembuatan kisi-kisi, penilaian validitas dan dilakukan pengujian untuk menghitung tingkat validitas dan reliabitasnya.

Sebelum soal tes kemampuan 
heuristik pemecahan masalah digunakan, terlebih dahulu untuk melihat validitas isi dan validitas muka. Validitas muka dilakukan dengan melihat tampilan dari soal itu yaitu keabsahan susunan kalimat atau kata-kata dalam soal sehingga jelas pengertiannya dan tidak salah tafsir atau kejelasan bahasa atau redaksional dan gambar atau representasi dari setiap butir tes yang diberikan. Jadi suatu instrumen dikatakan memiliki validitas muka yang baik apabila instrumen tersebut mudah dipahami maksudnya sehingga siswa tidak mengalami kesulitan ketika menjawab soal.. Validitas isi dilakukan dengan melihat kesesuaian materi tes dengan kisikisi tes, materi pelajaran yang telah diajarkan dan apakah soal pada instrumen penelitian sesuai atau tidak dengan indikator kemampuan yang diukur dan tingkat kesukaran untuk siswa.

Data dalam penelitian ini dikumpulkan melalui pretes dan postes pada kedua kelas, baik pada kelas eksperimen maupun kelas kontrol, diberikan pretes dan postes. Pretes dan postes terdiri dari dua jenis tes, yaitu tes untuk mengukur kemampuan heuristik pemecahan masalah matematis dan kuesioner skala sikap matematis untuk mengukur sikap matematis siswa pada saat diterapkan pendekatan PBL.

Data penelitian akan dikumpulkan melalui pretes dan postest siswa untuk melihat ketercapaian kemampuan pemecahan masalah siswa dikelas eksperimen dan kelas kontrol. Sedangkan untuk mengetahui sikap matematis pada siswa peneliti akan menggunakan angket yang akan diisi oleh anak setelah proses pembelajaran berlangsung baik dikelompok eksperimen maupun pada kelompok kontrol.

Analisis data yang digunakan, yaitu data kuantitatif berupa hasil tes kemampuan pemecahan masalah matematis dan sikap matematis siswa. Untuk menentukan uji statistik yang digunakan, terlebih dahulu diuji normalitas data dan homogenitas varians. Hipotesis yang diuji dalam penelitian ini sebagai berikut:

1. Hipotesis ke-1 yang diuji adalah:

$$
\begin{array}{rlr}
\mathrm{H}_{0}: & \begin{array}{l}
\text { Terdapat perbedaan } \\
\text { peningkatan kemamampuan }
\end{array} \\
& \begin{array}{l}
\text { heuristik pemecahan masalah } \\
\text { matematis siswa yang }
\end{array} \\
& \text { memperoleh } & \text { model } \\
& \text { pembelajaran PBL dengan } \\
& \text { siswa yang memperoleh } \\
\mathrm{H}_{1}: \text { : } & \text { Tidak terdapat perbedaan } \\
& \text { peningkatan kemamampuan } \\
& \text { heuristik pemecahan masalah } \\
& \text { matematis siswa yang } \\
& \text { memperoleh model } \\
& \text { pembelajaran PBL dengan } \\
& \text { siswa yang memperoleh } \\
& \text { pembelajaran biasa. }
\end{array}
$$

Hipotesis statistik sebagai berikut:

$\mathrm{H}_{0}: \mu_{e}=\mu_{k}$

$\mathrm{H}_{1}: \mu_{e} \neq \mu_{k}$

2. Hipotesis ke-2 yang diuji adalah:

$\begin{array}{rrr}\mathrm{H}_{0}: & \text { Terdapat perbedaan } \\ & \text { peningkatan } & \\ & \text { kemamampuan } & \text { sikap } \\ & \text { matematis siswa yang } \\ & \text { memperoleh } & \text { model } \\ & \text { pembelajaran } & \text { PBL } \\ & \text { dengan siswa yang } \\ & \text { memperoleh pembelajaran } \\ & \text { biasa. } \\ \mathrm{H}_{1}: & \text { Tidak terdapat perbedaan } \\ & \text { peningkatan } \\ & \text { kemamampuan } \\ & \text { matematis siswa yang } \\ & \text { memperoleh } & \text { model } \\ & \text { pembelajaran } & \text { PBL } \\ & \text { dengan siswa yang } \\ & \text { memperoleh pembelajaran }\end{array}$

Hipotesis statistik sebagai berikut:

$\mathrm{H}_{0}: \mu_{e}=\mu_{k}$

$\mathrm{H}_{1}: \mu_{e} \neq \mu_{k}$

Hipotesis ke-1 dan ke-2 diuji dengan menggunakan uji perbedaan dua rata-rata terhadap kelas eksperimen dan kelas kontrol. Menghitung indeks gain 
$\langle g\rangle$ ternormalisasi. Interpretasi indeks gain ternormalisasi dilakukan berdasarkan kriteria indeks gain dengan rumus $\mathrm{N}$-gain ternormalisasi sebagai berikut:

$$
N-\text { Gain Ternormalisasi }\langle g\rangle=\frac{\text { Skor Postest }- \text { Skor Pretes }}{\text { Skor Ideal }- \text { Skor Pretes }}
$$

Hasil perhitungan gain kemudian diinterpretasikan dengan menggunakan klasifikasi $\mathrm{N}$-Gain ternomalisasi sebagai berikut:

Tabel 1

Klasifikasi Gain Ternormalisasi

\begin{tabular}{|c|c|}
\hline Besarnya Gain $<\mathrm{g}>$ & Klasifikasi \\
\hline $\mathrm{g} \geq 0,70$ & Tinggi \\
\hline $0,30 \leq \mathrm{g}<0,70$ & Sedang \\
\hline $\mathrm{g}<0,30$ & Rendah \\
\hline
\end{tabular}

Sebelum dilakukannya pengolahan data dengan menggunakan SPSS 22.0 forwindows, maka terlebih dahulu perlu ditetapkan taraf signifikannya, yaitu $\alpha=$ 0,05 . Selanjutnya sebelum dilakukan uji hipotesis, terlebih dahulu perlu dilakukan uji normalitas distribusi data dan homogenitas variansi. Penjelasan uji normalitas dan uji homogenitas sebagai berikut :

1. Uji Normalitas

Uji normalitas dilakukan untuk mengetahui kenormalan data untuk menentukan uji yang digunakan selanjutnya apakah menggunakan statistik parametrik atau statistik nonparametrik. Hipotesis yang akan diuji adalah:

$\mathrm{H}_{0}$ : data sampel berasal dari populasi yang berdistribusi normal

$\mathrm{H}_{1}$ : data sampel berasal dari populasi yang tidak berdistribusi normal

Kriteria pengujian adalah terima $\mathrm{H}_{0}$ apabila Sig. $>\alpha$ dengan $\alpha$ pada taraf signifikansi $(\alpha=0,05)$

2. Uji Homogenitas Varians

Pengujian homogenitas adalah pengujian mengenai sama tidaknya variansi-variansi dua buah distribusi atau lebih. Uji homogenitas bertujuan untuk mengetahui data mempunyai varians yang sama atau tidak. Jika data mempunyai varians yang sama maka kelompok tersebut dinyatakan homogen. Hipotesis yang diajukan adalah :

$\mathrm{H}_{0}$ : data populasi memiliki varians yang sama

$\mathrm{H}_{1} \quad$ : data populasi tidak memiliki varians yang sama

Sedangkan kriteria pengujian hipotesis tersebut adalah :

- Jika nilai signifikansi > 0,05; maka terima $\mathrm{H}_{0}$

- Jika nilai signifikansi $\leq 0,05$; maka tolak $\mathrm{H}_{0}$

3. Teknik Uji perbedaan dua rata-rata $(\mathrm{N}$ gain)

Uji homogenitas ini diuji dengan menggunakan statistik uji Levene pada SPSS 22.0 for windows dengan kriteria jika nilai Sig (p) $>\alpha$, maka dapat disimpulkan Varians kelas kontrol dan kelas eksperimen sama.

Jika sebaran data normal dan homogen, dilakukan dengan Independent Samples t-Test (uji-t) dengan kriteria pengujian terima $\mathrm{H}_{0} \mathrm{jika}$ Sig. Equal Variances Assumed > dari taraf signifikan $(\alpha=0,05)$, jika sebaran data normal dan tidakhomogen 
dilakukan uji-t' dengan kriteria pengujian terima $\mathrm{H}_{0}$ jika Sig. EqualVariances Not Assumed > dari taraf signifikan $(\alpha=0,05)$ dan jika sebaran datatidak normal dan tidak homogen, dilakukan dengan uji nonparametrik UMann Whitney (2independent Samples).

\section{Hasil Penelitian dan Pembahasan}

Sesuai dengan metode penelitian yang digunakan, data yang diperoleh berupa data pretes dan postes untuk mengukur peningkatan kemampuan heuristik pemecahan masalah dan sikap matematis siswa pada kelas eksperimen dan kelas kontrol.

\section{Hasil Penelitian}

Hasil perhitungan kemampuan heuristik dan sikap matematis siswa dari output SPSS ditunjukkan pada tabel 2 di bawah ini:

Tabel 2

Uji Kesamaan Rata-rata Skor Pretes

\begin{tabular}{|c|c|c|c|c|c|c|c|}
\hline $\begin{array}{c}\text { Aspek } \\
\text { Kemam } \\
\text { puan }\end{array}$ & Kelompok & Mean & $\begin{array}{c}\text { St. } \\
\text { Deviasi }\end{array}$ & $t_{\text {hitung }}$ & Sig. & $\begin{array}{l}\text { Kesim } \\
\text { pulan }\end{array}$ & Ket. \\
\hline \multirow{2}{*}{ Heuristik } & Eksperimen & 13,92 & 3,632 & \multirow{2}{*}{1,870} & \multirow{2}{*}{0,166} & \multirow{2}{*}{$\begin{array}{c}\text { Terima } \\
\mathrm{H}_{0}\end{array}$} & \multirow{2}{*}{$\begin{array}{l}\text { Tidak ada } \\
\text { perbedaan }\end{array}$} \\
\hline & Kontrol & 12,38 & 2,753 & & & & \\
\hline \multirow{2}{*}{ Sikap } & Eksperimen & 49,15 & 6,214 & \multirow{2}{*}{$\begin{array}{c}- \\
1,437\end{array}$} & \multirow{2}{*}{0,156} & \multirow{2}{*}{$\begin{array}{c}\text { Terima } \\
\mathrm{H}_{0}\end{array}$} & \multirow{2}{*}{$\begin{array}{l}\text { Tidak ada } \\
\text { perbedaan }\end{array}$} \\
\hline & Kontrol & 51,29 & 5,306 & & & & \\
\hline
\end{tabular}

Berdasarkan tabel 4.5 di atas dapat disimpulkan:

a. Pada aspek kemampuan heuristik, nilai signifikansi output SPSS lebih besar dari $\alpha=0,05$, maka hipotesis $\mathrm{H}_{0}$ diterima artinya tidak terdapat perbedaan kemampuan awal antara siswa kelas kontrol dan kelas eksperimen.

b. Pada aspek sikap matematis, nilai signifikansi output SPSS lebih besar dari $\alpha=0,05$, maka hipotesis $\mathrm{H}_{0}$ diterima artinya tidak terdapat perbedaan kemampuan awal antara siswa kelas kontrol dan kelas eksperimen.

Dengan demikian disimpulkan bahwa sebelum diberi perlakuan, kedua kelompok memiliki kemampuan yang setara antar kelompok eksperimen dan kelas kontrol.Hasil SPSS 22.0 for Windows kemampuan heuristi dan sikap matematis siswa setelah perlakuan ditunjukkan pada tabel 3di bawah ini:

Tabel 3

Uji Perbedaan Rata-rata Skor Postes

\begin{tabular}{|l|l|c|c|c|c|c|}
\hline $\begin{array}{c}\text { Aspek } \\
\text { Kemampuan }\end{array}$ & Kelompok & Mean & $\begin{array}{c}\text { St. } \\
\text { Deviasi }\end{array}$ & $t_{\text {hitung }}$ & Sig. & Kesimpulan \\
\hline \multirow{2}{*}{ Heuristik } & Eksperimen & 25,81 & 3,533 & 8,423 & 0,000 & Tolak $\mathrm{H}_{0}$ \\
\cline { 2 - 7 } & Kontrol & 18,38 & 3,266 & & Tolak $\mathrm{H}_{0}$ \\
\hline \multirow{2}{*}{ Sikap } & Eksperimen & 63,19 & 4,099 & \multirow{2}{*}{3,840} & 0,000 & \\
\cline { 2 - 7 } & Kontrol & 59,32 & 3,682 & & & \\
\hline
\end{tabular}

Pada tabel 3 untuk kedua aspek, nilai signifikansi output SPSS kurang dari $\alpha=0,05$, maka hipotesis $\mathrm{H}_{0}$ ditolak.
Dengan demikian hipotesis $\mathrm{H}_{1}$ yang merupakan hipotesis penelitian diterima, jadi: 
a. Pada aspek kemampuan heuristik pemecahan masalah matematis dengan rata-rata skor kelas eksperimen 25,81 dan kelompok kontrol 18,38 dapat disimpulkan bahwa "Kemampuan heuristik pemecahan masalah matematis yang memperoleh pembelajaran Problem Based Learning (PBL) lebih baik daripada kemampuan heuristik pemecahan masalah matematis yang memperoleh pembelajaran biasa."

b. Pada aspek sikap matematis dengan rata-rata skor kelas eksperimen 63, 19 dan kelompok kontrol 59,32 dapat disimpulkan bahwa "Kemampuan sikap matematis yang memperoleh pembelajaran Problem Based Learning $(P B L)$ lebih baik daripada sikap matematis yang memperoleh pembelajaran biasa."

Untuk mengetahui peningkatan heuristik pemecahan masalah dan sikap matematis siswa yang memperoleh pembelajaran PBL pada kelas eksperimen dan kelas kontrol, dilakukan dengan menggunakan gain ternormalkan pada kedua kelompok.Hasil SPSS 22.0 for Windows ditunjukkan pada tabel 4 di bawah ini:

Tabel 4

Uji Perbedaan Rata-rata Gain Skor Postes

\begin{tabular}{|c|c|c|c|c|c|c|}
\hline $\begin{array}{c}\text { Aspek } \\
\text { Kemampuan }\end{array}$ & Kelompok & Mean & $\begin{array}{c}\text { St. } \\
\text { Deviasi }\end{array}$ & $t_{\text {hitung }}$ & Sig. & Kesimpulan \\
\hline \multirow{2}{*}{$\begin{array}{l}\text { Kemampuan } \\
\text { Heuristik }\end{array}$} & Eksperimen & 0,66 & 0,19 & \multirow{2}{*}{8,084} & \multirow{2}{*}{0,000} & \multirow[t]{2}{*}{ Tolak $\mathrm{H}_{0}$} \\
\hline & Kontrol & 0,30 & 0,16 & & & \\
\hline \multirow{2}{*}{$\begin{array}{l}\text { Sikap } \\
\text { Matematis }\end{array}$} & Eksperimen & 0,44 & 0,12 & \multirow{2}{*}{5,463} & \multirow{2}{*}{0,000} & \multirow[t]{2}{*}{ Tolak $\mathrm{H}_{0}$} \\
\hline & Kontrol & 0,27 & 0,12 & & & \\
\hline
\end{tabular}

Pada tabel 4 untuk kedua aspek, nilai signifikansi output SPSS kurang dari $\alpha=0,05$, maka hipotesis $\mathrm{H}_{0}$ ditolak. Dengan demikian hipotesis $\mathrm{H}_{1}$ yang merupakan hipotesis penelitian diterima, jadi:

a. Pada aspek kemampuan heuristik pemecahan masalah matematis dengan rata-rata skor gain ternormalkan kelas eksperimen 0,66 dan kelompok kontrol 0,30 dapat disimpulkan bahwa "Kemampuan heuristik pemecahan masalah matematis yang memperoleh pembelajaran PBL lebih baik daripada kemampuan heuristik pemecahan masalah matematis yang memperoleh pembelajaran biasa."

b. Pada aspek sikap matematis dengan rata-rata skor gain ternormalkan kelas eksperimen 0,44 dan kelompok kontrol 0,27 dapat disimpulkan bahwa "Kemampuan sikap matematis yang memperoleh pembelajaran PBL lebih baik daripada sikap matematis yang memperoleh pembelajaran biasa."
Berdasarkan kesimpulan yang diperoleh dari uji hipotesis di atas, diketahui bahwa terdapat perbedaan yang signifikan pada rata-rata skor gain antara kelas eksperimen dan kelas kontrol. Perbedaan yang signifikan tersebut merupakan pengaruh dari perlakuan yang berbeda di mana kelas eksperimen menggunakan pembelajaran PBL sementara kelas kontrol menggunakan pembelajaran biasa.

\section{Pembahasan}

Berdasarkan analisis tes awal pada kelas eksperimen dan kelas kontrol diperoleh kesimpulan bahwa kemampuan awal kemampuan heuristik pemecahan masalah matematis siswa tidak terdapat perbedaan secara signifikan. Namun setelah diberi perlakuan kemudian diberikan tes akhir, kemampuan heuristik pemecahan masalah matematis siswa ternyata pada kelompok eksperimen lebih baik daripada kelas kontrol. Hal ini disebabkan pada kelas eksperimen terjadi interaksi yang baik antara siswa dengan 
siswa dan antara siswa dengan guru. dalam kerja kelompok, aktivitas pembelajaran siswa terarah dan jelas, proses abstraksi dalam menyelesaikan soal pemecahan masalah dilakukan oleh siswa dengan baik, dapat mengembangkan ide, kreativitas, dan potensi siswa dalam menyelesaikan soal pemecahan masalah, dan terciptanya suasana belajar yang menyenangkan bagi siswa yang dapat mendorong persaingan yang sehat antar siswa.

Dari hasil analisis dapat juga disimpulkan bahwa kemampuan heuristik pemecahan masalah matematis siswa pada kelas eksperimen mengalami peningkatan yang signifikan. Peningkatan kemampuan heuristik pemecahan masalah matematis siswa tergambar pada grafik di bawah ini:

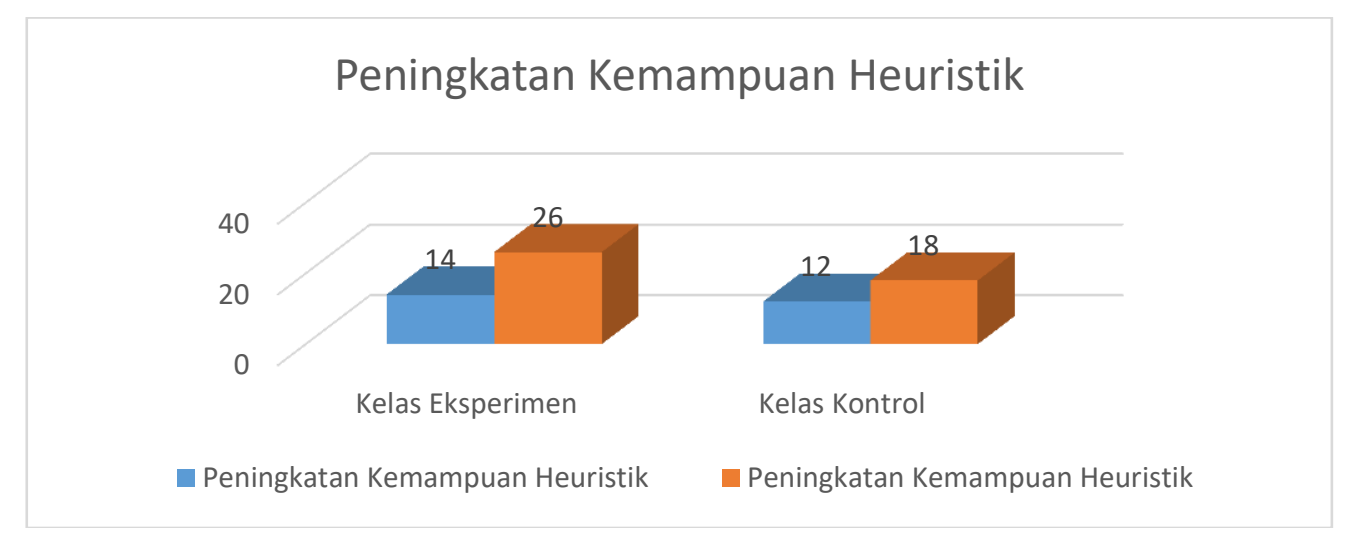

Grafik 1

Peningkatan Rata-rata Kemampuan Heuristik Pemecahan Masalah Matematis

Dari grafik di atas terlihat bahwa pada kelas eksperimen rata-rata skor pretes kemampuan heuristik pemecahan masalah matematis adalah 14, setelah mendpat perlakuan pembelajaran Problem Based Learning $(P B L)$ kemampuan rata-rata heuristiknya menjadi 26 dari skor ideal 32. Sementara pada kelas kontrol rata-rat pretesnya 12 dan postesnya meningkat menjadi 18 dari skor ideal 32.

Dari sebelas strategi heuristik pemecahan matematika yang dikemukakan oleh Reys dalam Aisyah (2008, hlm. 5-11) yaitu: 1) Beraksi (Act It Out)(S1), 2) Membuat Gambar atau Diagram (S2), 3) Mencari Pola (S3), 4) Membuat Tabel
(S4), 5) Menghitung Semua Kemungkinan secara Sistematis (S5). 6) Menebak dan Menguji (S6), 7) Bekerja Mundur (S7), 8) Mengidentifikasi Informasi yang diinginkan (S8), 9) Menulis Kalimat Terbuka (S9), 10) Menyelesaikan Masalah yang Lebih Sederhana atau Serupa (S10), 11) Mengubah Pandangan (S11), yang paling banyak digunakan oleh siswa dalam menyelesaikan soal pemecahan masalah tentang bangun datar adalah strategi beraksi, membuat gambar atau diagram, membuat tabel, mencari pola, dan bekerja mundur. Seperi yang terlihat pada tabel di bawah ini:

Tabel 5

Pengunaan Heuristik dalam Penyelesaian Soal Bangun Datar

\begin{tabular}{|c|c|c|c|c|c|c|c|c|c|c|c|}
\hline No. Soal & S1 & S2 & S3 & S4 & S5 & S6 & S7 & S8 & S9 & S10 & S11 \\
\hline 1 & 5 & 26 & - & - & - & - & - & - & - & - & - \\
\hline 2 & 8 & 24 & - & - & - & - & - & - & - & - & - \\
\hline 3 & - & 26 & - & - & - & - & - & - & - & - & - \\
\hline 4 & - & 26 & - & - & - & - & - & - & - & - & - \\
\hline
\end{tabular}




\begin{tabular}{|c|c|c|c|c|c|c|c|c|c|c|c|}
\hline No. Soal & S1 & S2 & S3 & S4 & S5 & S6 & S7 & S8 & S9 & S10 & S11 \\
\hline 5 & - & 24 & 14 & 7 & - & - & - & - & - & - & - \\
\hline 6 & - & 20 & 18 & 9 & - & - & - & - & - & - & - \\
\hline 7 & - & 25 & 10 & - & - & - & - & - & - & - & - \\
\hline 8 & - & 26 & - & - & - & - & 7 & - & - & - & - \\
\hline
\end{tabular}

Dari tabel di atas terlihat bahwa sebagian besar sisa dalam menyelesaikan soal pemecahan masalah pada materi bangun datar menggunakan heuristik membuat gambar atau diagram. Hal ini disebabkan karena penyelesaian masalah bangun datar bagi siswa sekolah dasar memerlukan visualisasi untuk memudahkan pemahaman dan penyelesaian terhadap soal-soal tentang bangun datar. Pada tabel di atas terlihat, bahwa pada nomor $1,2,5,6,7$, dan 8 dalam menyelesaikan soal-soal tersebut siswa menggunakan gabungan beberapa heuristik.
Pada penyelesaian soal nomor 1 dan 2 beberapa siswa menggunakan gabungan heuristik beraksi (act it out) dengan membuat gambar dan diagram. Pada heuristik beraksi, siswa menggunakan kertas berpetak sebagai alat untuk manipulasi penyelesaian soal dan dilanjutkan dengan menggambarnya pada lembar jawabannya. Sedangkan pada soal nomor $5,6,7$, dan 8 , pertama-tama siswa menggunakan heuristik membuat gambar dan diagram lalu dalam penyelesainnya dilanjutkan dengan heuristik yang lainnya, yakni heuristik mencari pola, membuat tabel, dan bekerja mundur. Hal ini dapt dilihat pada gambar di bawah ini:

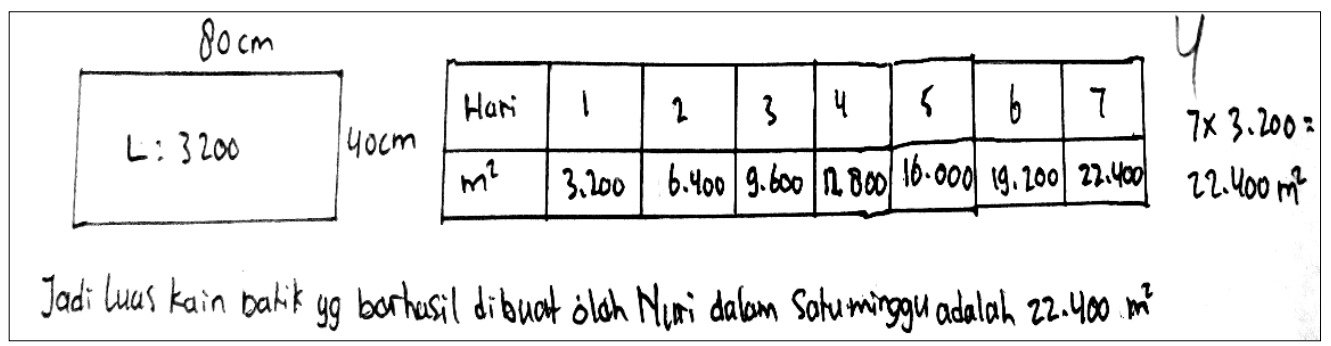

Dari gambar tersebut terlihat bahwa dalam menyelesaikan soal, pertama-tama siswa menggunakan heuristik membuat gambar dan diagram lalu dilanjutkan menggunakan heuristik mencari pola dalam bentuk tabel untuk menyelesaikan soal tersebut.

Dari tabel 5 juga terlihat bahwa dari 11 heuristik Model Reys tidak dapat dikembangkan semua dalam penelitian ini. Hal ini disebabkan karena dalam penelitian ini terbatas pada materi bangun datar. Sementara karakteristik materi bangun datar tidak dapat mengembangkan 11 heuristik Model Reys secara menyeluruh. Bagi peneliti selanjutnya yang ingin mengembangkan kemampuan heuristik pemecahan masalah siswa sekolah dasar, seyogyanya dapat memlilih dan mengembangkan materi yang dapat mencakup 11 kemampuan heuristik Model Reys.

Dari beberapa kondisi di atas, dapat dijelaskan bahwa pertama, pada pembelajaran kelas eksperimen siswa dalam kelompoknya berperan aktif sebagai pemecah masalah. Siswa dituntun dan dituntut dapat menemukan dan menyelesaikan soal pemecahan masalah dengan berbagai strategi heuristik pemecahan masalah. Terjadinya interaksi yang baik antara siswa dalam kelompok maupun antara kelompok dalam kelas. Sesuai dengan pendapat Pierce dan Jones (Rusman 2012:242) kejadian yang harus muncul dalam implementasi PBL adalah: (1) keterlibatan yaitu mempersiapkan siswa untuk berperan sebagai pemecah masalah dengan bekerja sama, (2) inquiry dan investigasi yaitu mengeksplorasi dan 
mendistribusikan informasi, performansi yaitu menyajikan temuan, (4) tanya jawab tujuannya untuk menguji keakuratan dari solusi, (5) refleksi terhadap pemecahan masalah.

Kedua, bahwa pemecahan masalah sangat penting bagi siswa seperti pendapat As'ari (1992, hlm. 22) bahwa pemecahan masalah merupakan hal yang perlu diperhatikan dalam pengajaran matematika. Pada pembelajaran kelas eksperimen yang disajikan dalam bentuk masalah memberikan semangat dan motivasi yang tinggi pada siswa dalam setiap kelompok untuk bersaing menemukan penyelesaian melalui berbagai strategi heuristik pemecahan masalah. Kepuasan akan tercapai apabila siswa dapat memecahkan masalah yang dihadapinya. Kepuasan ini akan berdampak positif bagi perkembangan intelektual siswa.

Ketiga, siswa diperlakukan sebagai siswa aktif yang diberi keleluasaan untuk mengembamgkan pengetahuannya. Siswa yang lemah dapat belajar dari pemikiran teman sebayanya yang berkemampuan lebih. Guru berindak sebagai fasilitator untuk dapat membangun pengetahuan secara kolaboratif. Barrow dalam Lidinillah (2008) bahwa Problem Based Learning $(P B L)$ terdiri dari lima karakteristik, yakni 1) Learning is studentcentered, 2) Authentic problems form the organizing focus for learning, 3) New information is acquired through selfdirected learning, 4) Learning occurs in small groups, 5) Teachers act as facilitators.

Keempat, pembelajaran pada kelas eksperimen memberikan kemampuan straregi heuristik yang baik pada siswa. Kemampuan pemecahan masalah merupakan hal yang sangat penting bagi siswa. Hal ini akan memberikan bekal kepada siswa untuk dapat menyelesaikan masalah dalam kehidupan sehati-harinya, karena masalah yang muncul dalam kehidupan sehari-hari tidak berbentuk suatu paket model matematika. Masalah biasanya berupa kata-kata atau peristiwa yang penyelesaiannya membutuhkan keterampilan. Sesuai dengan pendapat Branca (dalam Alam dan Pathudin, 2002, hlm. 60) menegaskan bahwa kemampuan pemecahan masalah adalah merupakan tujuan umum dan kemampuan dasar dalam pembelajaran matematika. Dengan demikian, pemecahan masalah memiliki peran penting dan inti dalam pembelajaran matematika.

Berdasarkan uraian pembahasan di atas dapat disimpulkan alasan perbedaan kemampuan heuristik pemecahan masalah antara siswa pada kelas eksperimen dan dan kelas kontrol adalah penggunaan model pembelajaran yang berbeda. Pada kelas kontrol siswa tidak memiliki kesempatan melakukan kegiatan-kegiatan bermakna dalam mengembangkan kemampuan heuristik pemecahan masalah sebagaimana yang dilakukan pada kelas eksperimen. Sedangkan pada kelas eksperimen dengan menggunakan model pembelajatran Problem Based Learning $(P B L)$, siswa melakukan proses abstraksi dengan baik, menemukan dan menggunakan strategi heuristik sesuai dengan tahapan seperti yang diungkapkan oleh Forgaty (Wena, 2010, hlm. 98) tahaptahap strategi PBL adalah sebagai berikut: 1) menemukan masalah; 2) mengidentifikasi masalah; 3) mengumpulkan fakta; 4) menyusun hipotesis; 5) melakukan penyelidikan; 6) menyempurnakan permasalahan yang telah didefinisikan; 7) menyimpulkan alternatif pemecahan secara kolaboratif; 8) melakukan pengujian hasil solusi pemecahan masalah.

Berdasarkan analisis sikap awal siswa sebelum perlakuan tidak memiliki perbedaan yang signifikan. Nilai rata-rata sikap awal siswa pada kelas kelas eksperimen adalah 49,15 dan nilai rata-rata sikap awal siswa pada kelas kontrol adalah 51,29 dari skor ideal 80. Hasil pengolahan data postes sikap siswa kelas eksperimen lebih tinggi daripada kelas kontrol. Nilai rata-rata kemampuan sikap siswa kelas 
eksperimen adalah 63,19 sedangkan kelas kontrol 59,32 dari skor ideal 80. Tingginya nilai rata-rata kelas eksperimen daripada kelas kontrol dipengaruhi oleh kegiatan di pembelajaran kelas eksperimen yang lebih menyenangkan dan lebih melibatkan siswa dalam kelompok untuk menyelesaikan masalah yang diberikan. Peningkatan sikap matematis siswa antara kelas eksperimen dan kelas kontrol juga dapat dilihat dari peningkatan rata-rata pretes ke rata-rata postenya, seperti tergambar pada grafik di bawah ini:

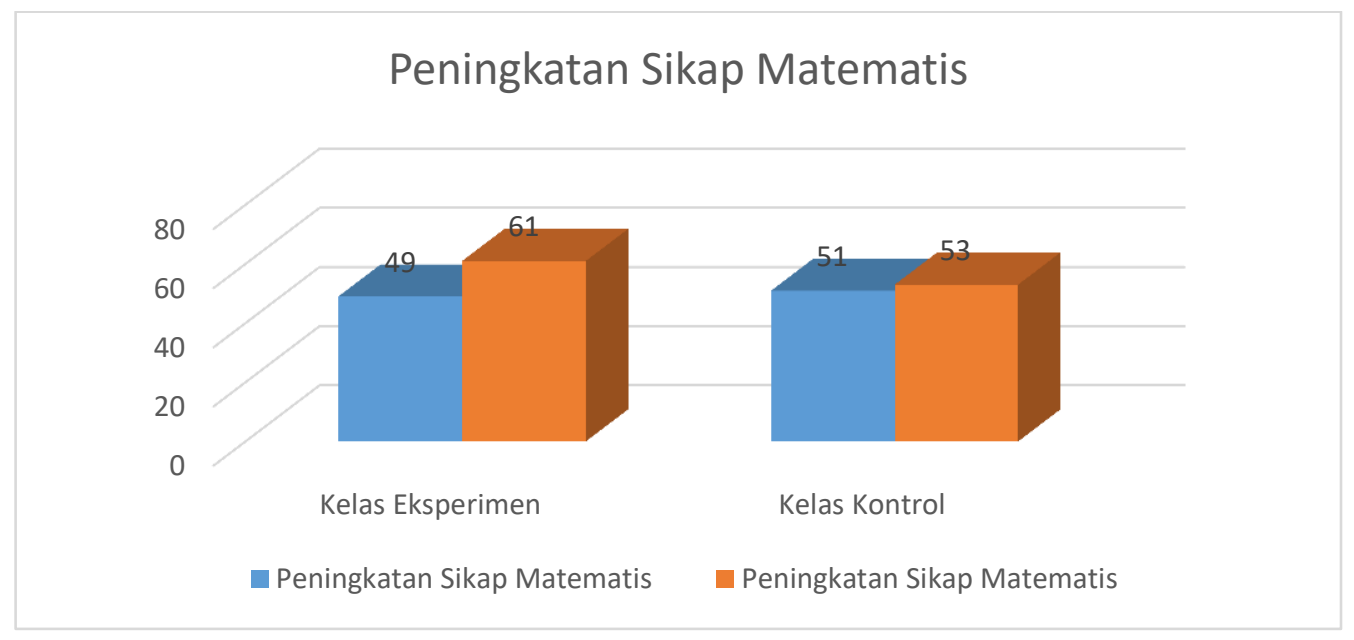

Grafik 2

Peningkatan Rata-rata Sikap Matematis

Dari grafik di atas terlihat bahwa pada kelas eksperimen rata-rata skor pretes sikap matematis adalah 49, setelah mendpat perlakuan pembelajaran Problem Based Learning (PBL) kemampuan ratarata sikap matematisnya menjadi 61 dari skor ideal 80. Sementara pada kelas kontrol rata-rat pretesnya 51 dan postesnya meningkat menjadi 53 dari skor ideal 80 .

PBLpada kelas eksperimen mampu menumbuhkan sikap positif siswa terhadap matematika. Seperti yang diungkapkan Syah (2010, hlm. 132), bahwa sikap adalah gejala internal yang berdimensi afektif berupa kecenderungan untuk mereaksi atau merespon (response tendency) dengan cara yang tetap terhadap objek orang, barang, dan sebagainya, baik secara positif maupun negatif. Ketika sikap positif terhadap matematika terbangun pada diri siswa, maka pembelajaran matematika akan lebih bermakna dan pencapaian pada tujuan pembelajaran matematika akan tercapai dengan baik.
Dari data hasil penelitian dapat disimpulkan bahwa terdapat peningkatan sikap siswa yang signifikan pada kelas eksperimen dibandingkan dengan kelas kontrol. Hal ini menunujukkan bahwa penerapan PBL berpengaruh baik terhadap peningkatana sikap maatematis siswa. Sikap siswa terhadap matematika sangat berpengaruh bagi keberhasilan pembelajaran matematika. Sikap positif siswa akan menunjukkan tindakan yang selalu mengarah pada upaya pencapaian tujuan pembelajaran matematika.

\section{Kesimpulan dan Saran}

\section{Kesimpulan}

Berdasarkan hasil analisis dan pembahasan serta temuan- temuan yang diperoleh dalam penelitian ini, maka dapat disimpulkan beberapa hal sebagai berikut:

a. Siswa yang mendapatkan model pembelajaran PBL mengalami peningkatan pada kemampuan strategi heuristik pemecahan masalah 
matematis yang lebih baik dibandingkan dengan siswa yang mendapatkan pembelajaran biasa.

b. Siswa yang mendapatkan model pembelajaran PBL mengalami peningkatan pada kemampuan strategi heuristik pemecahan masalahmatematis yang lebih baik dibandingkan dengan siswa yang mendapatkan pembelajaran biasa.

\section{Saran}

Berdasarkan kesimpulan dan implikasi penelitian diajukan beberapa saran sebagai berikut:

a. Berdasarkan data hasil penelitian, disarankan model pembelajaran PBLuntuk menjadi salah satu pilih model pembelajaran guru dalam meningkatkan kemampuan heuristik pemecahan masalah dan sikap matematis siswa.

b. Pembelajaran PBL membutuhkan waktu yang cukup lama, oleh karena itu perlu diperkirakan alokasi waktu yang cukup dalam membuat rencana pelaksanaan pembelajaran yang akan dilakukan.

c. Untuk peneliti selanjutnya, disarankan untuk mencari dan mengembangkan materi lain yang dapat mengembangkan 11 heuristik Model Reys secara menyeluruhdengan menggunakan pembelajaran model pembelajaran PBL.

\section{E. Daftar Pustaka}

Aisyah, N. (2008). Pengembangan pembelajaran matematika sekolah dasar. Jakarta: Depdiknas.

Alam , N \& Pathuddin. 2002. Pemecahan masalah dalam matematika. Kreatif. Jurnal Pendidikan dan Seni. 5 (3) : 59 -72).

Arends, R.I. (2008). Learning to Teach Belajar untuk Mengajar.
Yogyakarta. Pustaka Pelajar. Edisi Ketujuh.

As'ari, A.R. 1992. Kegiatan Pemecahan masalah dalam pembelajaran matematika.Majalah Eksakta, 21 (60): $13-22$.

Komariah. (2007) Model pemecahan masalah melalui pendekatan realistik pada pembelajaran matematika SD. Jurnal Pendidikan Dasar Volume 5 Nomor 7.

Lidinillah, D.A.M. (2008). Strategi pembelajaran pemecahan masalah di sekolah dasar. Jurnal Pendidikan Dasar No. 10 Tahun 2008.

McMillan, J.H. and Schumacher, S. (2001). Research in educations a conceptual introduction. addison Wesley Longman, Inc. Fifth Edition

Rusman. (2012). Model-model pembelajaran mengembangkan profesional guru. Jakarta : Raja Grafindo Persada.

Suherman, E. (2001). Strategi pembelajaran matematika kontemporer. Jurusan Pendidikan Matematika Universitas Pendidikan Indonesia, Bandung.

Syah M. (2010). Psikologi pendidikan. Bandung. PT Remaja Rosdakarya.

Wardhani, S. Dkk. ((2010). Pembelajaran kemampuan pemecahan masalah matematika di SD. Pusat Pengembangan dan Pemberdayaan Pendidik dan Tenaga Kependidikan (PPPPTK) Matematika

Wena, M. (2010). Strategi pembelajaran inovatif kontemporer suatu tujuan konseptual operasional. Jakarta. Bumi

Aksara. 